11. Wallin R, Martin LF 1987 Warfarin poisoning and vitamin K metabolism in rat and human liver. Design of a system in vitro that mimics the situation in vivo. Biochem J 241:389-396

12. Fasco MJ, Principe LM $1982 \mathrm{R}$ - and S- warfarin inhibition of vitamin K and vitamin $\mathrm{K} 2$,3-epoxide reductase activities in the rat. J Biol Chem 257:48944901

13. Wallin R, Patrick SD, Ballard JO 1986 Vitamin K antagonism of coumarin intoxication in the rat. Thromb Haemost 55:235-239

14. Esmon CT, Suttie JW 1976 Vitamin K-dependent carboxylase. Solubilization and properties. J Biol Chem 251:6238-6243

15. Martin LF, Patrick SD, Wallin R 1987 DT-diaphorase in morbidly obese patients. Cancer Lett 36:341-347

16. Reiderer BM, Zagon IS, Goodman SR 1987 Brain spectrin (240/235) and brain spectrin $(240 / 235 \mathrm{E})$ : differential expression during mouse brain development. J Neurosci 7:864-874

17. Wallin R, Martin LF 1988 Early processing of prothrombin and factor X by the vitamin K-dependent carboxylase. J Biol Chem 263:9994-10001

18. Laemmli UV 1970 Cleavage of structured proteins during the assembly of the head of bacteriophage TL. Nature 227:680-685

19. Sadowski JA, Esmon CT, Suttie JW 1976 Vitamin K-dependent carboxylase. Requirements of the rat liver microsomal enzyme system. J Biol Chem 251:2770-2776
20. Bartlett GR 1958 Phosphorus assay in column chromatography. J Biol Chem 234:466-468

21. Lu AYH, West SB 1980 Multiplicity of mammalian microsomal cytochromes P-450. Pharmacol Rev 31:277-295

22. Sann L, Leclercq M, Troncy J, Guillaumond M, Berland M, Coeur P 1985 Serum vitamin $K_{1}$ concentration and vitamin $K$-dependent clotting factor activity in maternal and fetal cord blood. Am J Obstet Gynecol 153:771774

23. Kries RV, Shearer MJ, Göbel U 1988 Vitamin K in infancy. Eur J Pediatr 147:106-112

24. Suttie JW 1978 Vitamin K. In: Decluca HF (ed) The Fat Soluble Vitamins, Handbook of Lipid Research, Vol 2. Plenum Press, New York, pp 21 1-277

25. Aballi AJ, De Lamerens S 1962 Coagulation changes in the neonatal period and in early infancy. Pediatr Clin North Am 9:785-817

26. Dube B, Dube RK, Bhargava V, Kolindewala JK, Kota VLN, Das BK 1986 Hemostatic parameters in new born. I. Effect of gestation and rate of intrauterine growth. Thromb Haemost 55:47-50

27. Shapiro AD, Jacobson LJ, Armon ME, Manco-Johnson MJ, Hulac P, Lane PA, Hathaway WE 1986 Vitamin K deficiency in the newborn infant: prevalence and perinatal risk factors. J Pediatr 109:675-680

28. Bohme HJ, Sparmann G, Hofmann E 1983 Biochemistry of liver development in the perinatal period. Experientia 39:473-483

\title{
Announcement
}

\section{Pediatric Critical Care Medicine Examination}

The

990.

The following criteria must be met to be eligible to sit for the examination: 1 . Certification by the American Board of Pediatrics. 2 . Subspecialty Training or Experience. Three years of full-time subspecialty residency training in pediatric critical care medicine is required of those physicians entering training on or after January 1, 1988. Physicians who entered training prior to January 1, 1988, may apply for admission on the basis of their completion of two years of training in pediatric critical care medicine. No foreign training will be accepted. $O R$ Certification in pediatric cardiology, neonatal-perinatal medicine, pediatric pulmonology, or anesthesiology based on completion of the full-time residency training requirements plus two years of training in pediatric critical care medicine. Physicians who entered training in pediatric critical care medicine prior to January 1,1988 , will need only one year of training. $O R$ Five years of broadly based pediatric critical care medicine. A minimum of $50 \%$ of full-time professional activities must be spent in pediatric critical care medicine to receive credit. These five years should be of such type and quality that they substitute for the clinical exposure one might have encountered during subspecialty training. All pediatric critical care medicine experience must be accrued before December 31, 1991. OR a) Those applicants who completed less than 12 months of subspecialty residency training in pediatric critical care medicine may receive credit on a month-for-month basis. b) Those applicants completing 12 to 23 months of subspecialty residency training in pediatric critical care medicine may receive credit on a two-for-one basis. The above credit added to practice experience must total 60 months or five years. These five years must be accrued prior to December 31, 1991. NO CREDIT FOR PARTIAL TRAINING WILL BE GIVEN FOR SUBSPECIALTY RESIDENTS WHO BEGAN THEIR TRAINING AFTER JANUARY 1, 1988. 3. Verification of training and recommendation by Program Director.

Each application will be considered individually and must be acceptable to the Sub-board of Pediatric Critical Care Medicine. Registration will extend from SEPTEMBER 1, 1989 to NOVEMBER 30, 1989. Requests for applications received prior to September 1, 1989, will be held on file. The application fee for the examination is \$1000, but applications postmarked after NOVEMBER 30, 1989, must include an additional \$200 late fee. NEW APPLICATIONS POSTMARKED AFTER DECEMBER 30, 1989, CANNOT BE ACCEPTED FOR THE 1990 EXAMINATION. Please direct inquiries to the American Board of Pediatrics, 111 Silver Cedar Court, Chapel Hill, NC 27514-1651. Telephone: (919) 929-0461. 